\title{
Losing Equilibrium: On the Existence of Abraham Wald's Fixed-Point Proof of 1935
}

\author{
E. Roy \\ Weintraub
}

Duke University
Till Düppe

Université du Québec à Montréal

July 27, 2015

ERID Working Paper Number 191

This paper can be downloaded without charge from the Social Science Research Network Electronic Paper Collection:

http://ssrn.com/abstract=2636557

\section{Economic Research Initiatives at Duke WORKING PAPERS SERIES

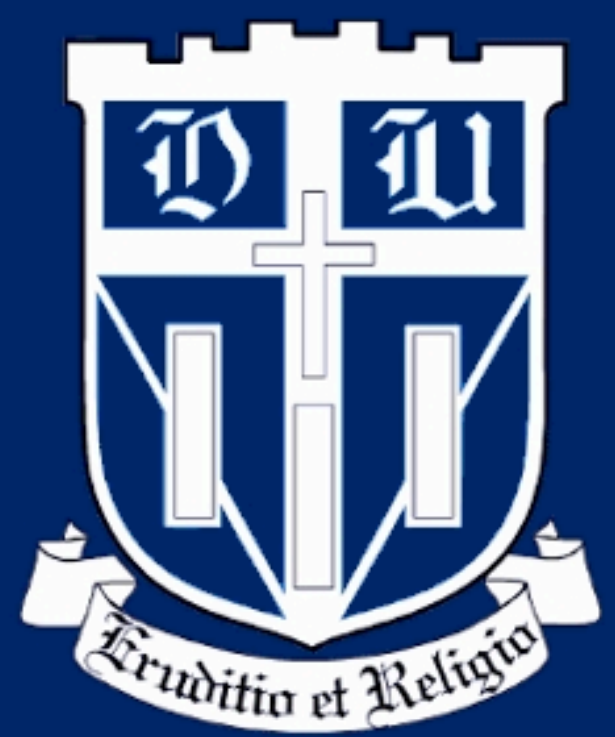




\title{
Losing Equilibrium
}

On the Existence of Abraham Wald's Fixed-Point Proof of 1935

Till Düppe and E. Roy Weintraub

July 2015

\begin{abstract}
In fall 1935, Abraham Wald presented an existence proof for a general equilibrium of exchange model to Karl Menger's Mathematical Colloquium in Vienna. Due to limited space, the paper could not be printed in the eighth proceedings of the Colloquium (the Ergebnisse) published in spring 1937 but was scheduled for the ninth issue of the series. After the annexation of Austria to Nazi Germany in March 1938 however, Menger's Colloquium ended and the proof never appeared in print. Nor did Wald, after he fled to the U.S. and launched a career in statistics, pursue the diffusion of his proof. Since the proof never appeared, there has been continued speculation about whether Wald's missing proof employed a fixed-point theorem. To date this question has remained unanswered. After his sudden death in 1950, only Wald's preliminary proof of 1934 was translated into English for Econometrica. When thus Arrow, Debreu, and McKenzie in 1954 referred in their own fixed-point proofs only to Wald's preliminary published version, his 1935 proof was forgotten. This did not change when economists and historians of economics, the authors included, reconstructed Wald's contribution. The authors' new evidence, however, establishes that the missing proof employed a fixed-point theorem. This article tells the story of Wald's lost equilibrium proof.
\end{abstract}

\section{JEL Codes: B2, B3, C6}

Key-Words: Fixed-point theorem, general equilibrium theory, Vienna Mathematical Colloquium, Karl Menger, Abraham Wald.

Word-Count: ca. 8000 


\section{Losing Equilibrium}

On the Existence of Abraham Wald's Fixed-Point Proof of 1935

Wald is really clever. I regard these works as very significant. They shed new light on the application of mathematics in economics. From now on, one can no longer persist in economics without mathematics - Hayek, by the way, is a dullard.* (Morgenstern in his diary, November 2, 1935')

\section{Wald's Private Lessons}

Abraham Wald stuck out as a student at the University of Vienna. He was an Ostjude, an Eastern Jew from Siebenbürgen (Transylvania) and thus was a member of the poor immigrant community that flooded Vienna after World War I. The immigrants from the eastern parts of the former Austro-Hungarian Empire created a number of problems for interwar Vienna. Vienna's intellectual elite looked down upon them. The established Viennese Jewish community, with such luminaries as Sigmund Freud, Otto Neurath, and Hans Mayer were uncomfortable with their mostly poor co-religionists. Wald's identifiable accent and appearance made his life

\footnotetext{
${ }^{1}$ Quotations with an asterisk * were translated from the German by Till Düppe.
} 
difficult in this time of continuing political strife between liberal Vienna and the nationalist parties. It was a time of economic crisis and increased overt anti-Semitism. Nor was Wald's former "home" politically more friendly. After the break-up of the Austro-Hungarian Empire in 1918, his Hungarian hometown Kolozsvár became the Romanian city Cluj, and he found himself unable to speak his new country's language. He could neither return easily to the new Romania, nor as a Jew was he eligible to find academic employment in Austria. ${ }^{2}$

His heart was with mathematics. In 1927 he became a student of the geometer Karl Menger, son of economist Carl Menger. Both Menger and Wald had been born in 1902, and at the time of their connection were in their mid 20s. Though Wald hardly ever attended classes, his talent became clear to Menger when in early 1930 Wald improved one of Menger's results regarding the concept of "betweenness" in metric spaces (Menger 1952: 14). Menger quickly invited him to join his mathematical colloquium, the Mengerkreis, that convened bi-weekly in a dingy room on the ground floor of the mathematics and physics department in Boltzmanngasse. The seminar was just in its second year and included young mathematicians such as Kurt Gödel, Franz Alt, and Georg Nöbeling. Geometry and topology figured prominently. Wald presented his results on the "axiomatic of the concept of metric betweenness" in May 1930 (in Menger 1998: 135). This was just months after John von Neumann, then Privatdozent in Berlin, gave his first talk in the Colloquium in January 1930 on measure theory (ibid.: 128). With the group's emphasis on geometry, Brouwer's 1909 fixed-point theorem was common knowledge in this circle. Menger had already spoken about the theorem in 1928 (ibid.: 95), and Nöbeling, another

\footnotetext{
${ }^{2}$ The most complete documentation about Abraham Wald is given in Leonard (2010: $150 \mathrm{ff}$ ). Published sources about Wald are mostly limited to obituaries written by former colleagues (Hotelling 1951, Menger 1952, Morgenstern 1951, Tintner 1952). A first historical account is Weintraub (1983), the most recent Weigl (2013).
} 
PhD student of Menger's, spoke about it in July 1930, two months after Wald's first talk (ibid.:

137). The theorem was thus part of Wald's mental furniture.

Wald graduated in 1931 with a thesis titled Über das Hilbert'sche Axiomensystem (as a young man he had read Hilbert's Foundations of Geometry before he arrived in Vienna). Menger wanted him to remain active in the colloquium, but "[a]t that time of economic and incipient political unrest, it was out of the question to secure for him a position at the University of Vienna, although such a connection would certainly have been as profitable for that institution as for himself' (Menger 1952: 18). Thus Wald had to return to Cluj since he lacked the money to live on in Vienna. He did not want to lose touch with Menger though and regularly sent letters to him containing new ideas, including full expositions of proofs. "My prospects of getting a position [in Cluj] are not favorable", he wrote on July 15, 1932. "I would be extremely happy if it would be possible for me to do scientific studies for a year in Vienna*" (MP 5: Wald). Menger wanted that as well, and he explored ways to bring Wald back to Vienna.

Outside of the Colloquium, my friend Hahn was the only mathematician who knew Wald personally. No one else showed the slightest interest in his work. However, Wald, with his characteristic modesty, told me that he would be perfectly satisfied with any small private position which would enable him to continue his work in our Mathematical Colloquium. I remembered that my friend Karl Schlesinger, a well-to-do banker and economist, wished to broaden his knowledge of higher mathematics; so I recommended Wald to him. (Menger 1952: 8) 
Menger had known Schlesinger from the banker's connection to his father's (Carl Menger's) economists' circle, the Nationalökonomische Gesellschaft (Austrian Economics Society). He also knew Oskar Morgenstern, an economist who was then director of the Austrian Institute for Business Cycle Research, from that group. ${ }^{3}$ Both Schlesinger and Morgenstern were enthusiastic about the possible uses of mathematics in economics, yet neither knew much mathematics. Consequently Wald secured a "tutoring job" giving private lessons to each of them. He would return to Vienna in December 1932.

Wald's financial security seemed assured for the next several years when Morgenstern managed to employ him as a temporary assistant at his institute; soon, thanks to the funds from the Rockefeller Foundation, Morgenstern turned the temporary position into a permanent one. At the institute, Wald primarily worked on methods to treat seasonal fluctuations in data series, work that he turned into a book in 1936. In his private lessons, both Schlesinger and Morgenstern shared their interests in economics, and in this manner Wald learned the basics of "marginalist" economics. The more Morgenstern saw the expressions of Wald's talent, the more he developed a "strong desire to interest him genuinely and more fully in economics and statistics" (Morgenstern 1951: 362). Even if Wald got to know the economics literature only from afar, and even if Morgenstern was far from being able to incorporate all the mathematics he learned in his own work, Morgenstern appreciated Wald's judgment to the point that he even made submissions of articles dependent on Wald's approval. ${ }^{4}$ Morgenstern's esteem for Wald grew just as his enthusiasm about the use of mathematics grew, and even as his knowledge of not

\footnotetext{
${ }^{3}$ The institute was founded 1927 by Hayek, and would receive support from the Rockefeller Foundation.

${ }^{4}$ See Wald's comments to Morgenstern on his "Vollkommene Vorraussicht und wirtschaftliches Gleichgewicht" in his letter from August 2, 1935 (MP 5: Wald), and Morgenstern's diary entry (OMP, 26.12.1935).
} 
knowing enough of it grew as well. However, he might not have shown his admiration openly to Wald, or to any other person. On this matter Leonard speculated: "Publicly, the imperious Morgenstern seems to have kept Wald at arm's length, with letters remaining formal even years later, and he never wrote publicly of taking lessons from him" (Leonard 2010: 154).

\section{Three Proofs}

In 1914 Schlesinger had published a book on money and the Walrasian system, and although he never sought nor had an academic position he had a long time interest in Walras's equations. As Morgenstern wrote in the International Encyclopedia of the Social Sciences

In his 1914 book Schlesinger made extensive use of some simple mathematics, uncommon at that time in German economic writing, particularly in the field of monetary theory... Schlesinger's

Theorie der Geld und Kreditwirtschaft made him the only immediate follower of Walras, other than Wicksell, to advance Walras' theory of money (1968: 509).

That would be one of the first theories Schlesinger would share with Wald. Schlesinger might have known of Robert Remak, a German mathematician who in 1929 and 1933, for a very simple model, showed that there was an unnoticed lacuna in previous contributions by Walras 
and Cassell. In counting equations and unknowns to establish the possibility of an equilibrium solution to the $n$ equations of general equilibrium, there was no reason to assume that such a solution would consist of nonnegative prices. The problem was already known to several people as Remak's idea was also taken up by Hans Neisser (1932) and Heinrich von Stackelberg in Germany (1933) as well as Franz Zeuthen in Denmark (1933). In order to rule out those cases in which some equilibrium prices might be negative, one had to assume that all prices were always non-negative. This then added $n$ inequalities to the $n$ equations to solve for $n$ non-negative prices. Questions of inequality rather than equality constraints became an issue. The problem seemed to be one of solving for $n$ unknowns that satisfied $n$ equations and $n$ inequalities. That was a natural starting point for discussions between Schlesinger and Wald.

Together Wald and Schlesinger worked on this problem and would separately present their preliminary results in the joint $74^{\text {th }}$ Mathematical Colloquium on March 19, 1934. Schlesinger presented the paper "Über die Produktionsgleichungen der ökonomischen Wertlehre" (1935), and Wald presented his paper "Über die eindeutige positive Lösbarkeit der neuen Produktionsgleichungen" (1935). The talks were a success though it was clear that much work remained. In a comment on Wald's paper published in the proceedings of that colloquium, Karl Menger wrote:

A very important task would now be to formulate sufficient and at the same time necessary conditions for the existence and uniqueness of the solutions of the new equations of production under the condition that the price of each unit of production not only depends on the quantity of that product but also on the 
quantity of the other products ... In any event I wish to remark in conclusion that with Wald's work we bring to a close the period in which economists simply formulated equations, without concern for the existence or uniqueness of their solutions, or at best, made sure that the number of equations and unknowns be equal (something that is neither necessary nor sufficient for solvability and uniqueness). Given that in one case - even if a mathematically low ranked case - the proof of existence and uniqueness has been successful, economists who formulate equations must henceforth (as the physicists have long done) deal explicitly with their solutions* (in Menger 1998: 290; see also Baumol and Goldfeld 1968: 288).

Schlesinger tried to talk Wald into submitting his article to the Zeitschrift für Nationalökonomie even though Wald thought of it simply as a mathematical contribution. ${ }^{5}$ But Wald must have been energized by Menger's support as he continued working on further generalizations. Eight months later he had a second proof that he presented in the $80^{\text {th }}$ Colloquium on November 6, 1934. His talk was titled "Über die Produktionsgleichungen der ökonomischen Wertlehre (2. Mitteilung)" and was published in the proceedings of 1936. Again, the talk was a great success. Morgenstern was present and even though he was certainly unable

\footnotetext{
5 "When I recently spoke to Dr. Schlesinger, we talked about the publication of my economic work. I told him that my part is so mathematical that its publication is only suitable in a mathematical journal. But he was decidedly against it and suggested to me that I publish my part, if you agree, in both the economic journal and the Ergebnisse"* (1968: 509, Wald to Menger, undated, after the first colloquium talk on equilibrium).
} 
fully to appreciate Wald's proof - in his private lessons he was just about to learn about "definite integrals" - he pushed for its publication.

Dozent Morgenstern immediately after the talk asked me to publish this work in the Vienna economic journal. I have not accepted for the reason that I first wanted to discuss this matter with Mr. Schlesinger. I visited Schlesinger this Friday and told him about Morgenstern's wish. He was against it and wants to publish it rather in an English [language] journal"* (Wald to Menger, undated, after second talk). ${ }^{6}$

Morgenstern would win over Schlesinger and Wald prepared a survey of his two papers for the non-mathematical audience of the Zeitschrift für Nationalökonomie.

Wald clearly knew that this was not the end of the story. He had not yet addressed the larger problem of proving the existence of equilibrium for an exchange economy. A proof of such a result seemed to require a more powerful set of tools, and his training in geometry suggested where those tools might be found. He appears to have settled on elaborating what he had called the "intermediate value theorem for a correspondence" which was in fact a onedimensional version of Brouwer's fixed-point theorem (Hildenbrand 1998: 56). Wald must have seen this and, while also working on the book on seasonal fluctuation, price indices, and the

\footnotetext{
${ }^{6}$ From Morgenstern's point of view: "In view of the significance of this work and the restricted character of the publication, Wald was persuaded to write and expository article for the Zeitschrift für Nationalökonomie" (1951: 363).
} 
axiomatization of probability theory ${ }^{7}$, he continued working on his third proof of existence using this theorem. In the next year, between November 1934 and November 1935, Wald put forward his third proof. Menger, as the Colloquium's director, certainly knew of Wald's effort, even though there is no mention in his correspondence with Menger of the techniques that Wald applied. ${ }^{8}$ But in his private lessons Wald spoke about his achievements: on November 2, 1935, Morgenstern noted in his diary

Another mathematical lesson, very interesting. I now feel that I make real progress. Wald has presented his new work. An astonishing thing: it is not sufficient, as Walras has thought, to assume monotonically decreasing utility functions, since he has proven that many of them would never lead to an equilibrium in the case of simple exchange! Similar paradoxes regarding the addition of demand curves, which one has considered to be harmless! ... Wald is really clever. I regard these works as very significant”* (Morgenstern diary, November 2, 1935).

In fall 1935 Wald was ready to present his more general proof. It is difficult today to uncover the exact date of that presentation. On December 19, Morgenstern's diary noted that he had assisted the "recent meeting" of the Colloquium. The preceding diary entry had been for November 10. It must then have been in this period from November to early December 1935 that

\footnotetext{
${ }^{7}$ That work on "collectives" brought him in touch with Karl Popper in "Schlick's Philosophical Circle". ${ }^{8}$ During the same time, Menger himself was working on an economic topic - diminishing returns - that would appear in the Zeitschrift in $1936(\mathrm{a} / \mathrm{b})$.
} 
Wald presented his proof in a talk titled "Proof of the solution of the exchange equations in economics" (Beweis für die Lösbarkeit der Tauschgleichungen der Ökonomie). On December 20 Morgenstern once again enthused in his diary about the use of mathematics in economics while dreaming of his own book in economic theory:

I would very much like to write a systematic introduction to economic theory, but before [I have to] finish the other book, and [have to learn] much much more mathematics. Wald has to use for the solution of the Walrasian equations even the fixed-point theorem in topology! And Alt comes to use group theory in his beautiful study on the measurability of utility! On the top of it, type theory in concepts of foresight and risk. Gradually economics is really becoming a strict science and must put off its chatty tone and tattling character"*(Morgenstern diary, December 20, 1935 emphasis by authors).

Having presented his proof, Wald expected that it was going to be published in the proceedings for the year 1935/1936, in the eighth volume of the series. In fact, when he completed the final version of his survey article for the Zeitschrift that appeared in early 1936, he referred to his existence proof for the exchange economy in the following terms: 
The author has also investigated the question of the solubility of the equations of exchange in a market under perfect competition. Only the results of this investigation will be discussed here; the extensive exposition and the complete proof, for which subtle methods of modern mathematics had to be used, appear in No. 8 of Ergebnisse eines mathematischen Kolloquiums (Wald 1951 [1936]: 379/80, emphasis by authors).

It could have been either before or shortly after Wald's 1935 talk that Menger somehow learned of a talk on economic theory John von Neumann had given to the mathematics department of Princeton University in 1932. There were many possible links between the Princeton mathematicians, von Neumann, and Menger. One possible path from that mathematics talk to Menger could have been Gödel who visited the U.S. for the first time in 1933, and in 1934 gave a set of lectures at the Institute of Advanced Study, von Neumann's "home". In his talk, von Neumann had examined the dynamic version of Cassell's model and established the existence of a dynamic competitive equilibrium also by use of a fixed-point theorem ${ }^{10}$. The paper established in fact a stronger version of the previously known Brouwer's Fixed Point Theorem. He also developed the system of dual inequalities that were to be used in linear programming and connected those elements of his analysis to his earlier proof of the existence of equilibrium for

\footnotetext{
${ }^{9}$ At that time, the Institute was not yet in its new physical home. It was lodged in Fine Hall, home of Princeton's mathematics department.

${ }^{10}$ Cassell's Theoretische Sozialökonomie (1919), translated into English in 1924 as The Theory of Social Economy was, like Hicks' 1939 Value and Capital, divided into two parts, statics and dynamics. The static general equilibrium model of Part I was explored by Schlesinger and Wald. The dynamic general equilibrium model of Part II, a classical growth model really, was examined by von Neumann. Neither model was well-specified by Cassell. Curiously, there was no mention or citation of Leon Walras in either the German or English edition (Weintraub 1983, 3-5).
} 
two person zero-sum games. Menger wrote to von Neumann and asked him if he would submit that article for publication in the Ergebnisse without its having been presented at the Colloquium. Von Neumann accepted the offer.

Having made that editorial decision, Menger decided not to include Wald's third proof in the eighth Ergebnisse. That decision was over-determined. Considering that Wald's main focus, like Menger's, had been always with mathematics while economics was a side interest that emerged from his giving private lessons to Schlesinger and Morgenstern, maybe Menger believed that the result was intellectually dominated by Wald's mathematical results. Indeed, Menger considered Wald's recent work on the concept of "curvature" his "masterpiece in the field of pure mathematics" (1952: 16). ${ }^{11}$ Menger also valued Wald's work in probability theory, specifically his axiomatic account of "collectives" published in volume eight, more than he valued Wald's work on the fixed point proof. But maybe Menger also worried about the increasing anti-Semitic complaints about the "racial" profile of the colloquium, or maybe he thought that Wald's economic bona fides had been sufficiently developed (he had a forthcoming publication on price indices in the Zeitschrift for 1937). Perhaps he did not want to postpone the publication of von Neumann's paper because von Neumann's 1932 proof was chronologically prior to Wald's and he surmised that Wald's proof would be published later anyway. In any event Wald, by then co-editor of the Ergebnisse, accepted Menger's decision. Accordingly in May 1936 Menger informed von Neumann, who had already submitted his article at some point that spring, that his note was soon going to be published in volume eight. On June 2, 1936 von Neumann, then at the Institut Henri Poincaré, wrote to Menger

\footnotetext{
${ }^{11}$ Wald presented this to the Colloquium in June 1935 and it was published in the seventh issue of the proceedings.
} 
I am very grateful for the information about my fixed point note. I would ask that corrections be sent to Princeton. How many reprints ("Separata") are there usually, or how can I order extra reprints? I am also very curious to see what Wald has done with the fixedpoints"* (OMP 3: von Neumann, emphasis added by authors).

In the same month, in June 1936, Moritz Schlick, a member of the Vienna Circle, was shot and killed by a student in a stairway of the main building of the university.

In early 1937 volume eight appeared with von Neumann's article “Über ein ökonomisches Gleichungssystem und eine Verallgemeinerung des Brouwerschen Fixpunktsatzes" (1937). In the final section of that volume "Colloquium matters for the year 1935/1936" we find the following note:

Apart from those notes contained in this issue, among others, the following talks had been given: ${ }^{12}$ (...) A. Wald: proof of the solution of the exchange equations in economics (Beweis für die Lösbarkeit der Tauschgleichungen der Ökonomie). The publication of this article, which could not be carried out in this issue owing to a lack of space, will take place shortly (464).

\footnotetext{
${ }^{12}$ The obvious lapsus is that von Neumann's article was in fact not presented at the Colloquium.
} 
This was the very last page of the eighth proceedings, appearing in spring 1937. Soon after that publication, the future of the Colloquium became very uncertain. Menger left Vienna.

The political situation in Austria deteriorated from month to month. The Ergebnisse was criticized (with specific reference to Wald) for its large number of Jewish contributions just when I felt that we ought to honor that journal by making Wald co-editor. Issue 7 was edited by Gödel, Wald, and myself. But Issue 8 containing Wald's paper on collectives was destined to be the last of the series. Hahn was dead. Schlick had been assassinated. Viennese culture resembled a bed of delicate flowers to which its owner refused soil and light while a fiendish neighbor was waiting for a chance to ruin the entire garden. I left the country. (Menger 1952: 19)

Menger left for Notre Dame University in South Bend, Indiana and started teaching there in September 1937. Wald, at first, took over the organization of the Colloquium; it was still unclear whether Menger would return. In September and October 1937, Wald went to Switzerland for the Econometric Society meetings and spent some time working for the Geneva Research Center. Ragnar Frisch turned out to like his work on price indices. Wald got in touch with Harold Hotelling at Columbia and Henry Schultz at Chicago concerning his precarious 
status in Vienna. With Frisch's support, Wald found some doors to the U.S. slowly opening. ${ }^{13}$ In early 1938, Wald might have still worked on the publication of volume nine of the Ergebnisse, but all plans came to a definite end on March 15, 1938. He might have heard the cheering of the mass on Heldenplatz, a stones-throw away from the university, when Hitler gave his speech celebrating the Anschluss, the annexation of Austria to Nazi Germany. That same day, Wald lost his job, and Schlesinger shot and killed himself.

Without income and with the German anti-Semitic laws in place, Wald's situation got ever more perilous. Morgenstern, who at the time was visiting the U.S. on a Rockefeller Fellowship, was replaced as Institute Director by his former assistant, a Nazi, and so could no longer help him. Travel conditions for Romanian Jews changed from day to day. His hunt for jobs in Jerusalem and elsewhere in Palestine was fruitless. Then, he received an invitation to visit the Cowles Commission for Economic Research in the U.S.

\begin{abstract}
Although pleased, Wald was not eager to leave Vienna; however, in view of the political prospects in Europe I persuaded him to accept and assured him that his future as a statistician in America was certain. That was a safe prediction to make, but Wald's heart was still in pure mathematics. After some hesitation he decided to go to Colorado Springs [home of the Cowles Commission] and he never regretted this decision (Morgenstern 1951: 363).
\end{abstract}

\footnotetext{
${ }^{13}$ The details of the repeatedly frustrated efforts of winning a travel grant for Wald to the U.S., Morgenstern's role in it, Wald's further job hunt, and final arrangements with the Cowles Commission is well described by Leonard 2010: 173-180.
} 
Wald needed travel documents from Romania which he could not be certain of obtaining since he needed official permission to leave the country. He eventually secured that permission, embarking on the Queen Mary in Cherbourg on June 29. On the passenger manifest his profession was noted as "Professor", and his immigration status was noted as "Executive Order", which meant that he was in a special refugee category. ${ }^{14}$

It might be that he took his unpublished papers with him. It might be.

\section{Aftermath: A Statistician in the United States}

Moving to the U.S., for Wald, was a move away from pure mathematics. He became a statistician. His first publication in English would not be a translation of his equilibrium proof but rather his second article from the Zeitschrift of 1937 on price indices, which was published in Econometrica in 1939. After only a few months at Cowles, he received an invitation from Hotelling to become a research assistant in mathematical statistics at Columbia with the position funded by the Carnegie Corporation (Hotelling 1951: 18). From there Wald was to have a meteoric career trajectory up to the vice-presidency of the American Statistical Association in 1948. Wald still met his friend Menger each summer:

\footnotetext{
${ }^{14}$ In earlier work, Weintraub $(1983,1985)$ and Düppe and Weintraub (2014) wrote that Wald had come to the U.S. via Cuba. This information had been communicated to Weintraub in a 1982 letter from W. Allen Wallis. It is, however, not true, as was pointed out to the present authors by | Olav Bjerkholt.
} 
Economists and statisticians soon became aware of his potentialities, and from the outset he was gratified to feel that this country would make effective use of his talents and abilities. When he ceased working in the field of geometry, it was not for lack of interest. It was for lack of time. Whenever he and I met during the summer (we usually spent our vacations together in the mountains) we discussed both geometry and statistics (Menger 1952: 20).

There is no evidence that Wald further pursued his existence proof though he might have still had it in the bottom drawer of his desk. As his friend Jacob Wolfowitz said "he made no effort to popularize his ideas or to make them accessible to a less mathematical public" (1952: $5)$.

In 1941, Morgenstern wrote a review of Hicks' Value and Capital at the same time he was in the middle of working on his game theory book with John von Neumann (1944). In the review he repeatedly mentioned both of the Ergebnisse papers by von Neumann and Wald, and he did so without differentiating between them. He did not refer, however, to the unpublished paper by Wald. He only noted that in Wald's Zeitschrift paper "some further reference to literature may be found" (1941:369) which, as we have seen, includes the unpublished paper. It is not the case that Morgenstern had forgotten all about Wald's third proof since he would remember it even years later. But it might be that he did not appreciate, or no longer appreciated, its significance. Soon after the game theory book appeared in 1944, a translation of von Neumann's article was prepared by the early "computer scientist" George A. Morton and 
published in 1945 in the Review of Economic Studies as "A model of general economic equilibrium". That paper, as is well known, electrified mathematical economists for decades.

During the war Wald worked in Columbia's Statistical Research Group of the Applied Mathematics Panel where he solved a major problem in sequential analysis, effectively creating the idea of sequential sampling. At the end of WWII, Wald received the shocking news that eight of nine members of his close family, including his parents, had been killed in the gas chambers of Auschwitz. "Even this cruel blow failed to make him embittered", Morgenstern recalled, "although a certain sadness could be felt to be with him for the rest of his life. Later he succeeded in bringing the sole survivor, his brother Hermann, to this country, and he took great comfort in his company" (Morgenstern 1951: 366-7).

After WWII, Wald continued working side by side with Hotelling at Columbia. He also taught one of his economics PhD students, Kenneth Arrow. Arrow at that time was looking for a topic for his thesis and, after having gained an idea of the problem of existence of equilibrium from reading Hicks' Value and Capital, spoke to Wald.

It was after the War that I found out that Wald had worked on this problem. I asked him about it and all he said was: "Oh, yes, that is a very, very difficult problem". I thought that if he found it a difficult problem, it was probably nothing for me to touch (Arrow, in Feiwel 1987: 194). 
Over the next decade, however, Arrow began to wonder whether Wald himself had, in the unpublished third paper, employed a fixed-point theorem to establish existence. He had no particular reason to believe that this was the case, except for a vague feeling that it was likely that Wald saw the potential generalization of his "intermediate value theorem for a correspondence" and was attempting to employ a fixed point theorem to the static version of the Cassel model.

Wald's two proofs re-emerged publically in the run-up to the 1949 Conference on Activity Analysis of Production and Distribution organized by Tjalling Koopmans at Cowles in June 1949 (see Düppe and Weintraub 2014b). Both of the Wald papers were then translated for the RAND Corporation as part of its project on linear programming and they, in addition to von Neumann's paper, were made available to the conferees. In the proceedings itself there was hardly any paper that did not refer to John von Neumann's article. Yet apart from Koopmans (in his Introduction) nobody referred to Wald's paper. Morgenstern was present at the conference, but at this point of his career his was little inclined to champion Wald's third proof since his views had changed from those of his Vienna years; he now would rail against mathematical innovations in economic theory that did not use any data (Düppe and Weintraub 2014b).

In fall 1950, Wald was invited by the Indian Government to do a lecture tour. His wife, Lucille Lang, joined him. On one of the local flights on December 13, "in the fog of the steep Nilgiri mountains in the southern-most tip of India" (Morgenstern 1951: 361), the airplane crashed. Wald and his wife died (Mahalanobis 1951). Morgenstern wrote an obituary for Econometrica. Even though he had been present at Wald's talk in 1935, he did not mention the third proof. Morgenstern was no longer inclined to praise Walrasian economics, saying only that "the chief interest of [Wald's] research (on the Walras-Cassel system) was mathematical" (1951: 362). Gone was his earlier excitement that he wrote about in his Viennese diary entries. None of 
the other obituaries or encyclopedia entries, which mostly focused on Wald's work as a statistician, mentioned his third proof (Tintner 1952, Wolfowitz 1952, Freeman 1968). ${ }^{15}$ Certainly had Morgenstern mentioned Wald's proof that could have raised an interesting counterfactual: how might the community have appraised the originality of the Arrow, Debreu, and McKenzie proofs? Issues of priority would have arisen considering that priority was highly valued in the community of mathematical economists (see Düppe and Weintraub 2014).

The translation of Wald's Zeitschrift paper was reprinted in the same fall 1951 Econometrica issue in which Morgenstern's obituary for Wald was published. As the present authors have shown (2014), this translation had little impact on the work then being done by Arrow, Debreu and McKenzie who independently, in precisely those months of fall 1951, began thinking about establishing the existence of a competitive equilibrium using a fixed point theorem. Even though each of them developed his proof along different paths, von Neumann's Ergebnisse article was important for all of them. Wald's Zeitschrift article played no such role.

In the historical section of Arrow and Debreu's joint article, Arrow (rather than Debreu) would dedicate an entire page to explain in what sense their proof was more general than that of Wald's published second proof; Wald had assumed fixed proportions of inputs and outputs and what Samuelson has called the weak axiom of revealed preferences on an aggregate level. Wald's assumptions, particularly that demand functions are independent of the income distribution, effectively reduced the number of consumers to one. McKenzie referred to both von Neumann and Wald similarly, though he worried less about aggregate demand functions than he

\footnotetext{
${ }^{15}$ Nor did a 500 page dissertation dedicated solely to Abraham Wald mention his third proof (Weig1 2013).
} 
did about the strong assumption resulting in the weak axiom of revealed preferences. ${ }^{16}$ The last sentence of the Arrow-Debreu paper then read "it may be added that Wald has also investigated the uniqueness of the solutions; this has not been done here" (289) - which indeed remained a lacuna in the neo-Walrasian research program for the next 20 years.

This sentence about "uniqueness" is all that remained of Wald's contribution to the existence proof of a competitive exchange economy in general equilibrium theory. Arrow's, Debreu's and McKenzie's appraisal of Wald's contribution would become canonical. When in 1958 all the Ergebnisse “equilibrium” papers, Wald's and von Neumann's included, were discussed in the book by Dorfman, Samuelson and Solow (1958), the canonical representation of Wald's work reached an audience beyond the mathematical economics community. Wald's third equilibrium proof - whatever weaker assumptions he may have achieved by using the fixedpoint theorem - was lost both in fact and in history.

\section{The Proofs Become History}

In 1965, John Chipman first mentioned Wald's third proof in an English-speaking publication. In his Survey of the Theory of International Trade (II), he sketched parts of the history of Wald's third proof by referring to a letter from none other than Oskar Morgenstern.

\footnotetext{
${ }^{16}$ This assumption, for Wald, was the background for his statistical approach to decision theory (1954: 147).
} 
I quote from a letter to me dated November 18, 1963, from Professor Oskar Morgenstern: 'I saw last week Karl Menger in Chicago, and discussed with him in detail of the question you raised in your letter of August 15 regarding a paper by Wald. It is clear that everything that existed has been published. The paper you refer to was written but is lost. Probably Wald himself lost it when coming to this country and never bothered to rewrite it. There is no question that Wald had a proof for the exchange equilibrium, and it is a pity that we have no record of it other than the memory of the people who were associated with him at that time.' (Chipman 1965: 720, fn 18)

Even in the 1960s Morgenstern clearly remembered Wald's talk even though he had remained silent about it on several occasions.

The two Ergebnisse papers by Wald were not published in English until 1968 when they appeared in the volume Precursors in Mathematical Economics: An Anthology edited by William J. Baumol and Stephen Goldfeld. There Baumol also translated the Ergebnisse's editorial note about Wald's upcoming proof in the ninth issue: "the publication of this article, which could not be carried out in this issue owing to a lack in space, will take place shortly" (in Baumol 1968, 270).

After 1968 there was no further work on the history of general equilibrium theory, at least the mathematical developments of it, until E. Roy Weintraub's 1983 paper. In the year and a half that preceded publication of that paper, Weintraub attempted to get more information about the 
missing Wald paper. Kenneth Arrow wrote to him, concerning his own knowledge of the Wald work prior to his own existence proof. McKenzie wrote that he also knew of it. Specifically on January 6, 1982, McKenzie wrote to Weintraub commenting on a footnote constructed by Arrow and Frank Hahn in 1971 about the equivalence of McKenzie's and Wald's proof ${ }^{17}$ :

Their statement is true if we refer to Wald's paper on the exchange model. However this paper was not published and was apparently lost. Its theorem was stated but not proved in an article by Wald published in the Zeitschrift ... in 1936.

Thus for a period of time in the early 1980 s Weintraub was eager to locate the missing equilibrium paper. Where might it have gone?

There were only a few possibilities. First, perhaps the editor of the Ergebnisse, Karl Menger, had a copy but wasn't aware of it since his response to Morgenstern was that it must have been lost. Yet shortly after Weintraub's paper appeared, noting the lost Wald paper, Menger wrote to him asking for a couple of re-prints in the course of expressing his appreciation of the paper and citing no errors. He made no mention of the Wald paper. Shortly thereafter Menger passed away. His own papers were bundled up and moved into a storage closet in the mathematics department of the Illinois Institute of Technology. There they remained under the control of Professor Abe Sklar who intended to memorialize Menger by publishing a series of his

\footnotetext{
17 "McKenzie [1954] established an existence theorem that is more general than Wald's with regard to production assumptions; however, if specialized to the case of exchange, it is identical to Wald's" (Arrow and Hahn 1971: 51 note).
} 
mathematical papers in a volume of tribute. Sklar was not interested in having others come to the supply closet to rummage through the boxes looking for correspondence on an economics paper.

But what about Wald's papers? Wald had an office in the statistics department at Columbia University at the time of his sudden death. What had become of the contents of his office? Wald's literary executor was the distinguished statistician Jacob Wolfowitz whose obituary tribute to Wald appeared in the Annals of Mathematical Statistics (1952). Wolfowitz would certainly have known about the disposition of Wald's papers. He however had passed away by the time Weintraub first asked these questions in 1982. Perhaps he had retained some of Wald's papers? Weintraub got in touch with Wolfowitz's son, the Reagan [and later Bush] administration official Paul Wolfowitz, and asked him if he knew anything about the WolfowitzWald connection and Wald's possible remaining papers. Wolfowitz was interested in the puzzle and consequently looked through all of his father's materials that had remained at the family home but he was not able to locate anything from Wald.

Over the next few years Weintraub re-focused some of his questions and learned that Abraham Wald's oldest son, who had been three and a half years old at the time of his father's death, was a distinguished professor of theoretical physics at the University of Chicago. In an exchange of letters with Robert Wald, Weintraub learned that when Abraham and his wife had died, they had virtually no insurance and that the two children were taken to live with their mother's family in New Jersey. The grandmother was very upset that these two children were thrust upon her with no means of financial support. Following a suggestion from Robert Wald, Weintraub was able to track down the New Jersey law firm that had handled matters of the Wald's estate, and learned of the tension and anger. None of this of course got any closer to Wald's office contents, and any possible missing paper. Robert Wald meanwhile suggested that 
if his grandmother had had anything to do with it, she would have simply thrown out all of his father's things.

In the course of time the Menger papers found their way to the Economists' Papers Project at Duke University. Karl Menger's literary executer was his daughter, Eve Menger Hammond, who at the time of her father's death was a vice provost at the University of Virginia. Through her efforts and interest, the papers in the Illinois Institute of Technology mathematics department closet came to Duke but, because they were extensive and at that point the library was just beginning to support the Economists Papers Project, there were few resources for serious processing. The fact that much of the material was in German and pertained to his mathematical life also made the processing somewhat less timely although the materials from Karl's own father, Carl Menger, the founder of Austrian economics, were quickly used by scholars from around the world. Indeed, they were the basis for the first of the continuing annual HOPE Conferences.

In 1998 Egbert Dierker and Karl Siegmund edited and reprinted all of the volumes of the Ergebnisse. In that volume Hildenbrand wrote an exposition of Wald's proof and once more repeated what Arrow and Debreu had said about Wald's contribution. ${ }^{18}$ Karl Siegmund however discussed the circumstances surrounding Wald's third proof:

Wald, who (as a co-editor) allowed John von Neumann's paper to appear without any reference to his own contribution, had finished

\footnotetext{
18 "The existence proofs by Arrow and Debreu (1954) and McKenzie (1954) made Wald's theorem obsolete, since they did not need restrictive assumptions on the demand side of the economy. This achievement was possible by using Kakutani's fixed-point theorem. Wald's intermediate value theorem for a correspondence (Lemma 1, above) is, of course, a one dimensional version of Kakutani's fixed point theorem" (Hildenbrand 1998: 59).
} 
a further article on mathematical economics which he planned to publish in the following, ninth, volume of the series. In it he proved the existence of an equilibrium in a pure exchange economy, most probably also using Brouwer's fixed point theorem. We shall never know for sure: after the Anschluss ... the manuscript disappeared. 'Wald's lost paper' became a legend among mathematical economists (Siegmund 1998: 24).

With no hope of locating Wald's materials directly, and with Weintraub's confidence in Kenneth Arrow's "hunch" that Wald had constructed a fixed-point proof of existence of an exchange equilibrium, matters regarding the Wald legend seemed both tantalizing and frustrating. Finally, in the summer of 2014 Scott Scheall and Reinhard Schumacher, as incoming fellows of Duke's Center for the History of Political Economy, successfully put together finding aids for the Karl Menger papers, organizing and cataloging them in a useful fashion. One of the results of this activity was Düppe's discovery not only of a number of letters between Wald and Menger from the Vienna years, but also between John von Neumann and Karl Menger, confirming the fact that Wald had indeed employed a fixed point theorem to prove the existence of an equilibrium for an exchange economy. It was this discovery that has led us to write this addendum to our Finding Equilibrium (2014). 


\section{References}

Arrow, Kenneth J., and Gérard Debreu (1954). "Existence of an Equilibrium for a Competitive Economy." Econometrica 22 (3): 265-90.

Arrow, Kenneth, and Frank Hahn (1971). General Competitive Analysis. Amsterdam: Elsevier. Baumol and Goldfeld (1968). Series of Reprints of Scarce Works on Political Economy, \#19 London: London School of Economics and Political Science.

Debreu, Gérard (1998). "Foreword: Economics in a Mathematics Colloquium." in Ergebnisse eines Mathematischen Kolloquiums, edited by Karl Menger, Egbert Dierker, and Karl Siegmund. Wien: Springer: 1-4.

Dorfman, Robert, Paul Samuelson, and Robert Solow (1958). Linear Programming and Economic Analysis. New York: McGraw-Hill.

Düppe, Till (2012). “Arrow and Debreu de-homogenized," Journal of the History of Economic Thought, 34 (4): 491-514.

Düppe, Till and E. Roy Weintraub (2014a). Finding Equilibrium: Arrow, Debreu, McKenzie and the Problem of Scientific Credit. Princeton: Princeton University Press.

Düppe, Till and E. Roy Weintraub (2014b). "Siting the New Economic Science: The Activity Analysis Conference of June 1949”, Science in Context, 27 (3): 453-483.

Feiwel, George, editor (1987). Arrow and the Ascent of Modern Economic Theory. New York: New York University Press. 
Freeman, Harold (1968). “Abraham Wald”, in David L. Sills (editor), International Encyclopedia of Social Sciences, 16: 435-438.

Hildenbrand, Werner (1998). “An exposition of Wald's existence proof”. In Karl Menger et al. (editors). Ergebnisse eine Mathematischen Kolloqiums. Wien: Springer: 51-62.

Hotelling, Harold (1951). “Abraham Wald”, The American Statistician, 5 (1): 18-19.

Koopmans, Tjalling, editor (1951). Activity Analysis of Production and Allocation: Proceedings of a Conference. New York: Wiley.

Leonard, Robert. 2010. Von Neumann, Morgenstern, and the Creation of Game Theory: From Chess to Social Science, 1900-1960. Cambridge: Cambridge University Press.

Mahalanobis, Prasanta C. (1951). "In Memoriam: Abraham Wald”, Sankhyā: The Indian Journal of Statistics, 11 (1): 1-2.

McKenzie, Lionel (1954). “On Equilibrium in Graham's Model of World Trade and Other Competitive Systems.” Econometrica 22 (2): 147-61.

Menger, Karl (1936a). “(Weitere) Bemerkungen zu den Ertragsgesetzen”, Zeitschrift für Nationalökonomie, 6: 25-56.

Menger, Karl (1936b). “Weitere Bemerkungen zu den Ertragsgesetzen”, Zeitschrift für Nationalökonomie, 6: 388-397.

Menger, Karl (1952). "The Formative Years of Abraham Wald and His Work in Geometry". Annals of Mathematical Statistics, 23 (1): 14-20.

Menger, Karl (1998). Ergebnisse eines Mathematischen Kolloquiums. Edited by Dierker, Egbert, and Karl Sigmund. Wien: Springer. 
Menger, Karl Papers (MP). David M. Rubenstein Rare Book and Manuscript Library, Duke University.

Morgenstern, Oskar (1941). "Professor Hicks on Value and Capital.” Journal of Political Economy, 49 (3): 361-93.

Morgenstern, Oskar (1951). “Abraham Wald, 1902-1950”. Econometrica, 19 (4): 361-367.

Morgenstern, Oskar Papers (OMP). David M. Rubenstein Rare Book and Manuscript Library, Duke University.

Morgenstern, Oskar (1968). "Karl Schlesinger", International Encyclopedia of the Social

Sciences, 14. New York, Macmillan: 509: 511.

Neisser, Hans (1932). “Lohnhöhe und Beschäftigungsgrad im Marktgleichgewicht”, Weltwirtschaftliches Archiv, 36: 415-455.

Neumann, John von (1937). “Über ein ökonomisches Gleichungssystem und eine Verallgemeinerung des Brouwerschen Fixpunksatzes.“ Ergebnisse eines Mathematischen Kolloquiums, Heft 8 (1935-36). Edited by Karl Menger. Leipzig: Deuticke: 73-83. Translated by George Morton (1945). “A Model of General Economic Equilibrium”, Review of Economic Studies 13(1): 1-9.

Neumann, John von, and Oskar Morgenstern (1944). Theory of Games and Economic Behavior. Princeton: Princeton University Press.

Remak, R. (1929), "Kann die Volkswirtschaftslehre eine exakte Wissenschaft werden“, Jahrbücher für Nationalökonomie und Statistik, 131: 703-735; partially translated into English in: Baumol, Goldfeld (1968), 271-277. 
Remak, R. (1933), "Können superponierte Preissysteme praktisch berechnet werden?“, Jahrbücher für Nationalökonomie und Statistik, 138: 839-842.

Schlesinger, Karl (1914). Theorie der Geld- und Kreditwirtschaft. München: Duncker \& Humblot

Schlesinger, Karl (1935). "Über die Produktionsgleichungen der ökonomischen Wertlehre“, Ergebnisse eines mathematischen Kolloquiums, Heft 6:10-11.

Stackelberg, Heinrich von (1933). "Zwei kritische Bemerkungen zur Preistheorie Gustav Cassels”, Zeitschrift für Nationalökonomie, 4: 456-472.

Tintner, Gerhard (1952). "Abraham Wald's contributions to econometrics," Annals of Mathematical Statistics, 23: 21-28.

Uzawa, H., 1962, Walras' Existence Theorem and Brouwer's Fixed-Point Theorem, The Economic Studies Quarterly (13): 59-62.

Wald, Abraham (1935). "Über die eindeutige positive Lösbarkeit der neuen

Produktionsgleichungen," Ergebnisse eines mathematischen Kolloquiums, Heft 6 (1933-1934).

Edited by Karl Menger. Leipzig und Wien: Franz Deuticke: 12-18. Reprinted in Baumol and Goldfeld (1968). "On the Unique Non-negative Solvability of the New Production Equations, Part I.” Translated by William J. Baumol.

Wald, Abraham (1935). "Begründung einer koordinatenlosen Differentialgeometrie der Flächen“, Ergebnisse eines Mathematischen Kolloquiums, Heft 7: 24-46.

Wald, Abraham (1936). “Über die Produktionsgleichungen der ökonomischen Wertlehre (2. Mitteilung)," Ergebnisse eines mathematischen Kolloquiums, Heft 7 (1934-35). Edited by Karl Menger. Leipzig und Wien: Franz Deuticke: 1-6. Reprinted in Baumold and Goldfeld (1968). 
"On The Production Equations of Economic Value Theory, Part 2." Translated by William J. Baumol.

Wald, Abraham (1936). "Über einige Gleichungssysteme der mathematischen Ökonomie," Zeitschrift für Nationalökonomie, 7 (5): 637-70. Translated by Otto Eckstein (1951), “On Some Systems of Equations of Mathematical Economics," Econometrica, 19: 368-403.

Wald, Abraham (1936). Berechnung und Ausschaltung von Saisonschwankungen. Wien: Julius Springer.

Wald, Abraham (1952). "The Publications of Abraham Wald", The Annals of Mathematical Statistics, 23 (1): 29-33.

Weigl, Hans Günter (2013). Abraham Wald: a statistician as a key figure for modern econometrics. Ph.D Dissertation, Mathematics Department of the University of Hamburg, Germany.

Weintraub, E. Roy (1983). “The Existence of a Competitive Equilibrium: 1930-1954.” Journal of Economic Literature 21 (1): 1-39.

Weintraub, E. Roy (2002). How Economics Became a Mathematical Science. Durham: Duke University Press.

Wolfowitz, Jacob (1952). “Abraham Wald: 1902-1950”, Annals of Mathematical Statistics, 23: $1-13$.

Zeuthen, Franz (1933). "Das Prinzip der Knappheit, technische Kombinationen, und ökonomische Qualität”, Zeitschrift für Nationalökonomie, 4: 1-24. 